\title{
El rostro misionero de la parroquia. \\ Reflexión canónica-pastoral acerca de la parroquia a la luz de la carta apostólica Porta Fidei y de la XIII Asamblea General Ordinaria del Sínodo de los Obispos sobre La nueva evangelización para la transmisión de la fe cristiana
}

\author{
Marcelo Gidi Thumala \\ FACULTAD DE TEOLOGÍA \\ PONTIFICIA UNIVERSIDAD CATÓLICA DE CHILE \\ mgidi@uc.cl
}

\section{Nuestro objeto y objetivo}

El Mensaje Final al Pueblo de Dios del Sínodo de Obispos del año 2012 afirmaba que:

"En todos los lugares se siente la necesidad de reavivar una fe que corre el riesgo de apagarse en los actuales contextos culturales que obstaculizan su enraizamiento personal, su presencia social, la claridad de sus contenidos y sus frutos coherentes [...]. Los cambios sociales, culturales, económicos, políticos y religiosos nos llaman, sin embargo, a algo nuevo: a vivir de un modo renovado nuestra experiencia comunitaria de fe y el anuncio, mediante una evangelización"1.

Comunicar el Evangelio en un mundo que muta constantemente es, de hecho, la cuestión crucial. Por esto mismo la Iglesia propone renovarse recordando que su misión más propia, que la tarea fundamental a la que Jesús envía a sus discípulos, es el anuncio del Evangelio ${ }^{2}$.

1 Cf. Sínodo de Obispos de la XiII Asamblea General Ordinaria, Mensaje de conclusión, 2. Disponible en: <http://www.vatican.va/news_services/press/sinodo/ documents/bollettino_25_xiii-ordinaria-2012/04_spagnolo/b30_04.html>.

2 "Evangelizar constituye, en efecto, la dicha y vocación propia de la Iglesia, su identidad más profunda”. Cf. PABlo VI, Evangelii nuntiandii: exhortación apostólica sobre la evangelización en el mundo contemporáneo, 14. 
En este sentido, el papa Benedicto XVI ha afirmado que "La Iglesia en su conjunto ha de ponerse en camino"3. Y esto, para los Obispos del mundo reunidos en el Sínodo, es un problema eclesiológico que se refiere a la capacidad o incapacidad de la Iglesia de configurarse como real comunidad $^{4}$. Sí, este es el desafío que también propone a la Parroquia la Nueva Evangelización en el Año de la Fe: moverse, renovarse, ponerse en camino y salir de sí misma, si quiere configurarse como real comunidad, una comunidad de comunidades misioneras. Sin la parroquia no se puede realizar la Nueva Evangelización y la misma evangelización, si quiere ser nueva, implica una parroquia misionera, una parroquia de rostro nuevo ${ }^{6}$.

3 Benedicto xvi, Porta Fidei: Carta apostólica en forma de Motu proprio, 2. Un documento importante con el cual se da inicio al Año de la Fe con el deseo de introducir a todo el cuerpo eclesial en un renovado impulso en la misión. El M.p. Porta Fidei de Benedicto XVI, enfatiza en esta línea, que la puerta de la fe, se atraviesa cuando "La Iglesia en su conjunto, y en ella sus pastores, anuncia [...] la Palabra de Dios [...]" (nn.1-2). Que la evangelización, como acto de fe, "es un acto personal y al mismo tiempo comunitario. En efecto, el primer sujeto de la fe es la Iglesia" (n.10). Por eso, continúa la Carta Apostólica, también hoy es necesario un compromiso eclesial más convencido de todos, pastores y fieles, en favor de una nueva evangelización (n.7), por la que todos podrán adquirir una "exacta conciencia de su fe, para reanimarla, para purificarla, para confirmarla y para confesarla" (n.4). Lo anterior, porque la fe nunca es solo un hecho privado o personal, sino comunitario, y el anuncio de la Palabra nunca es un hecho individual, no es una empresa individualista y solitaria, sino más bien un evento comunional y comunitario que cuestiona a toda la Iglesia en su ser y en su vivir.

4 Cf. Sínodo de Obispos de la XIII Asamblea General Ordinaria, Lineamenta, 2 "La nueva evangelización para la transmisión de la fe cristiana"

5 El 25 de marzo de 2013, el papa Francisco escribe a los obispos argentinos: "Una Iglesia que no sale, a la corta o a la larga, se enferma en la atmósfera viciada de su encierro [...]. Ante esta alternativa, les quiero decir francamente que prefiero mil veces una Iglesia accidentada que una Iglesia enferma. La enfermedad típica de la Iglesia encerrada es la autorreferencial; mirarse a sí misma, estar encorvada sobre sí misma como aquella mujer del Evangelio. Es una especie de narcisismo que nos conduce a la mundanidad espiritual y al clericalismo sofisticado, y luego nos impide experimentar «la dulce y confortadora alegría de evangelizar»", FRANCISCO, Carta a los participantes en la 105a Asamblea Plenaria de la Conferencia Episcopal Argentina.

6 Cf. S. Silva, Sinodo de los Obispos, XIII Asamblea General Ordinaria, Relación de los Circulos Menores Hispanicus. [Fecha de consulta: marzo de 2013]. Disponible en: <http://www.vatican.va/news_services/press/sinodo/documents/bollettino_25_ xiii-ordinaria-2012/04_spagnolo/b24_04.html> 
En este artículo, desde el contexto de la Nueva Evangelización, quisiera, por un lado, analizar y reivindicar la importancia que la parroquia tiene en la tarea evangelizadora de la Iglesia y, por otro, la función que el párroco, pastor y guía de la comunidad, debe desarrollar junto a ella para afrontar con éxito los retos culturales y religiosos con los que se enfrenta en la actualidad. Este artículo no tiene como método de análisis la teología especulativa, es más bien una reflexión desde el método de la teología pastoral y, por lo mismo, práctica. El objeto central de análisis de este artículo es el ministerio de la Palabra, y su objetivo será examinar y analizar, jurídica y pastoralmente, en qué modo la normativa canónica sobre la parroquia y el párroco, establecida en el Código de Derecho Canónico vigente, es un sostén suficiente para que ella se renueve adecuadamente ${ }^{7}$. Nos preguntamos en este trabajo por la identidad teológica-jurídico-pastoral de la parroquia en el contexto de la Nueva Evangelización: ¿Cuál es el modelo eclesiológico adecuado que debe estructurar la parroquia para hacer visible en ella su carácter misionero y apostólico? ¿Qué estilo de comunidad parroquial se necesita para que ella siga ocupando un lugar central en la misión de la Iglesia y en la llamada Nueva Evangelización?

\section{La parroquia en el Código de Derecho Canónico}

El nuevo Código de Derecho Canónico (CIC/83) refleja con claridad la eclesiología conciliar ${ }^{8}$. En definitiva, fundamentado en el CVII, lo que

7 Nuestra tesis es que la Nueva Evangelización no solo se realiza una actividad, sino que, además, se edifica el cuerpo de las Iglesias particulares y más en general de cada comunidad cristiana. Es un instrumento y un medio espiritual y jurídico por el cual la Iglesia debe configurarse como una real comunidad, como verdadera fraternidad, como cuerpo (IL 39).

8 Algunos documentos conciliares señalan los elementos fundamentales que forman parte del concepto estático (qué es), y otros, al concepto dinámico (qué hace) la parroquia: Cf. SC 41-42; LG 26 y 38; CD 30; AG 27; PO 5. En este sentido son varias las formas con las cuales el CVII define la parroquia: es como la célula de la Iglesia particular (AA, 10), en cierto modo, representa la Iglesia visible establecida en toda la tierra (SC, 42); es la comunidad parroquial, CD 10g, 30bf, AG 37, SC 42; la comunidad de fieles, SC 42b, LG 26 y 28; PO 5; la asamblea local de fieles, LG 16, 28b. En esta perspectiva explicativa, los documentos conciliares describen a la parroquia de su constitución, como una determinada comunidad de fieles, desde su finalidad pastoral, para una mejor cura de las almas, desde una perspectiva misionera, como el lugar en el cual cada uno de los fieles adquiere conciencia de 
el CIC/83 quiere, es responder de una manera más dinámica el para qué hoy y el cómo de la parroquia?.

Siguiendo los principios eclesiológicos del CVII, el CIC/83 describe a la parroquia de manera más teológica y menos organizativa, más dinámica y menos administrativa, más integrada y menos dividida ${ }^{10}$. La parroquia está descrita, en el can. $515 \$ 1$, como: "Una determinada comunidad de fieles constituida de modo estable en la Iglesia particular, cuya cura pastoral, bajo la autoridad del Obispo diocesano, se encomienda a un párroco, como su pastor propio".

El Código considera a la parroquia, communitas christifidelium, primeramente como una determinada comunidad de bautizados, presidida ministerialmente por el párroco (cann. 204 y $529 \$ 2)^{11}$. Bajo estos términos, la parroquia ha sido descrita por el $\mathrm{CIC} / 83$ desde aquello que la ha constituido como un instrumento privilegiado de evangelización, que ha sido dotada de todos los medios adecuados para que en la construcción de lo que es, una communitas christifidelium, pueda manifestar

ser miembro activo del pueblo de Dios (SC 42 y AA 30c); modelo de apostolado comunitario (AA 18b; AA 10, 2; 18, 1-2; AG 15, 2).

9 Esta communitas fidelium, que es la parroquia, no se comprende solo desde sus estructuras puramente jurídicas, sino que principalmente desde la diversidad de carismas, vocaciones y ministerios que la integran; no desde la separación párrocofieles, sino desde la interacción e integración, unitaria y orgánica, de la variedad y diversidad de personas, que forman la única parroquia, el párroco junto a los demás fieles. Cf. F. Coccopalmerio, "Il concetto di parrocchia", en Il Codice del Vaticano II, La Parrocchia e le sue strutture (Bologna 1987) 64.

10 Congregación para el Clero, Instrucción: El presbitero, pastor y guía de la comunidad parroquial, 4-8-2002. Documento que se sitúa dentro de la gran corriente misionera del "duc in altum", que marca la obra indispensable de la nueva evangelización del Tercer Milenio cristiano, en su n.18, afirma que: "los rasgos eclesiológicos más significativos de la noción teológico-canónica de parroquia han sido concebidos por el Concilio Vaticano II a la luz de la tradición, de la doctrina católica y de la eclesiología de comunión, y traducidos más tarde en leyes por el Código de Derecho Canónico". [Fecha de consulta: diciembre de 2012]. Disponible en: <http://www.vatican.va/roman_curia/congregations/cclergy/documents/ rc_con_cclergy_doc_20020804_istruzione-presbitero_sp.html>

11 Referido a la parroquia, el término communitas expresa claramente su dimensión personal y su naturaleza relacional; naturaleza que se da con la Iglesia universal y particular, con las otras parroquias, asociaciones y otros movimientos, y con todas las categorías de fieles que forman parte de esa determinada comunidad eclesial (cann. 515 y 519). Cf. Communicationes, 13 (1981), 147. 
aquello para lo que fue instituida: una comunidad que, reunida en la Palabra de Dios, se hace una comunidad evangelizadora ${ }^{12}$.

\section{Documentos postcodiciales: La dimensión COMUnitaria y su DINAMISMO}

Hoy, como en las últimas décadas, en medio de tantas nuevas propuestas asociativas, la parroquia se encuentra amenazada por dos posibles distorsiones eclesiológicas: por una parte, el impulso de hacer de la parroquia una comunidad autorreferencial y, por otra, la percepción de la parroquia entendida como un centro de servicios especialmente sacramentales, y por lo tanto prescindible para la experiencia misionera y de fe. Ante estas equivocaciones que dañan mucho la comprensión de la parroquia en cuanto un bien precioso para la vitalidad del anuncio y de la transmisión del Evangelio, la misma Iglesia ha reaccionado.

Los distintos documentos magisteriales que hemos consultado señalan que la parroquia, considerada una protagonista necesaria de la Nueva Evangelización, necesita de una conversión pastoral. Necesita descubrir su nuevo rostro. Necesita cambiar su modo de comprenderse y estructurarse, necesita renovarse desde su naturaleza misionera y evangelizadora, necesita organizarse desde su dimensión comunitaria y eminentemente apostólica. En esta línea, creemos importante señalar que la renovación eclesiológica conciliar no solo tuvo impacto en la autocomprensión de la Iglesia universal, sino también, para la comprensión de la parroquia, como núcleo fundamental de la misión de la Iglesia de Cristo.

12 El Código señala de diversas maneras este carácter misionero y la índole comunitaria del apostolado parroquial, como parte fundamental del apostolado de aquella diócesis de la cual forma parte (cann. 518 y ss). En el documento de la Conferencia ePiscopal italiana, Nota Pastorale: Il volto missionario, 3, se lee: "La parrocchia è dunque una scelta storica della Chiesa, una scelta pastorale, ma non è una pura circoscrizione amministrativa, una ripartizione meramente funzionale della diocesi: essa è la forma storica privilegiata della localizzazione della Chiesa particolare". Nuestra traducción: "La parroquia es una elección histórica de la Iglesia, una opción pastoral, pero no es una simple circunscripción administrativa, una repartición meramente funcional de la diócesis: ella es una forma histórica privilegiada de la localización de la Iglesia particular". En ella aparece eminentemente la dimensión local, concreta y cercana de la eclesialidad, es comunidad de fe, de celebración, de caridad y de misión: PO 5-6; AG 15; LG 28, AA 30, SC 42; CD 32. Es clara esta opción eclesiológica para la ConGregación de los obispos, Directorio para el Ministerio de los Pastoral de los Obispos Apostolorum Sucesores, 214 a. 
En nuestro análisis y para el objetivo del mismo, creemos importante mencionar los siguientes documentos eclesiásticos.

La Exh. Ap. Christifideles laici afirma que, en cierto sentido, la parroquia es la Iglesia entre la gente. Para lo cual es indispensable una conversión de la parroquia hacia la misión. La Exhortación propone, en esta línea, a las autoridades diocesanas, una decidida renovación parroquial favoreciendo:

a) La adaptación de las estructuras parroquiales, sobre todo mediante la participación de los laicos en las responsabilidades pastorales.

b) La promoción de pequeñas comunidades que sean verdaderas expresiones de la comunión eclesial y centros de evangelización en comunión con sus pastores.

c) Formas institucionales de cooperación entre las diversas parroquias de un mismo territorio.

d) Una apertura cada vez mayor de los fieles a la Iglesia particular, así como una mayor cooperación en el ámbito diocesano, interdiocesano, nacional o internacional, teniendo presente las necesidades del Pueblo de Dios esparcido por toda la tierra ${ }^{13}$.

Diez años más tarde, Juan Pablo II, por medio de la Exh. Ap. Ecclesia in America ${ }^{14}$, reivindica la importancia eclesial de la parroquia. El Papa intuye que la parroquia cumple un rol insustituible en la promoción eclesial de la fe, cuando afirma que ella es "[...] un lugar privilegiado en el que los fieles pueden tener una experiencia concreta de la Iglesia” (EA 41). Entonces, la parroquia, si quiere estar a la altura de lo que ella es, ha de estar prioritariamente al servicio de los fieles para el encuentro con Jesucristo vivo, de la conversión personal y comunitaria, de la comunión eclesial, de la solidaridad y de la misión, y de las prioridades evangelizadoras de la Iglesia. Por lo mismo, el Papa afirma, si ellas quieren ser lo que son, deberán estar:

"[...]abiertas a la diversidad de carismas, servicios y ministerios, organizadas de modo comunitario y responsable, integradoras de los movi-

13 Juan Pablo II, Christifideles laici: Exhortación apostólica post-sinodal, 25-26, que en adelante abreviaremos ChL.

14 Juan Pablo II, Ecclesia in America: Exhortación apostólica post-sinodal, que en adelante abreviaremos EA. 
mientos de apostolado ya existentes, atentas a la diversidad cultural de sus habitantes, abiertas a los proyectos pastorales y supra-parroquiales, $y$ a las realidades circundantes (EA41)".

Poco tiempo después, el mismo pontífice, a través de la Exh. Ap. Novo Millenio Ineunte ${ }^{15}$, al concluir el Jubileo del año 2000, propone a todos los fieles a tomar conciencia de la propia responsabilidad en la vida y misión de la Iglesia ${ }^{16}$. En este contexto, reconoce la importancia de la parroquia en esta propuesta de diversidad en la unidad apostólica. Afirma que en la parroquia "Los espacios de comunión han de ser cultivados y ampliados día a día, a todos los niveles. En ella, la comunión ha de ser patente en las relaciones entre Obispos, Presbíteros y Diáconos, entre Pastores y todo el Pueblo de Dios, entre clero y religiosos, entre asociaciones y movimientos eclesiales" (NMI 45) ${ }^{17}$. La comunión se transforma en la condición de posibilidad no solo de una nueva relacionalidad, sino, también, de una renovada acción misionera que acabará por implicar la responsabilidad de todos los miembros del Pueblo de Dios.

Lo anterior lleva a la Congregación para el clero ${ }^{18}$, a afirmar que como pars dioecesis, los criterios de organización y gobierno, así como el significado de sus tareas apostólicas, deben ser entendidos y vividos, en la parroquia, con un sentido de comunión orgánica, de diálogo evangelizador entre el mundo y ella misma, entre el sacerdocio común y el sacerdocio ministerial y, por tanto, de colaboración fraterna y dinámica entre pastores y fieles en el más absoluto respeto de los derechos, deberes y funciones propias, donde cada uno tiene sus propias competencias y su propia responsabilidad ${ }^{19}$.

15 Juan Pablo II, Novo Millennio Ineunte: Carta apostólica, que en adelante abreviaremos NMI.

16 En línea con la unidad y participación de todos los fieles en la misión de la Iglesia. Lo que expresa la unidad que surge de la participación que a cada uno de los fieles le corresponde en las funciones de Cristo; indica la participación de los cristianos en los bienes de salvación: la caridad, la fe, la esperanza, la misión, los diversos carismas y dones que distribuye el Espíritu Santo en la comunidad.

17 "Es necesario, pues, que la Iglesia del tercer milenio impulse a todos los bautizados y confirmados a tomar conciencia de la propia responsabilidad activa en la vida eclesial” Juan Pablo II, NMI 46. Cf. NMI 40.

18 Congregación para el Clero, Instrucción: El presbitero, pastor y guía de la comunidad parroquial.

19 Congregación para el Clero, Instrucción: El presbitero, pastor y guía de la comunidad parroquial. 
A nivel continental, las Conferencias Generales del Episcopado Latinoamericano realizadas en Río de Janeiro (1955), Medellín (1968), Puebla (1979) y Santo Domingo (1992) han asumido y profundizado las reflexiones y orientaciones antes mencionadas sobre la parroquia. En sus conclusiones sobre la parroquia, desde el contexto misionero de su reflexión, enfatizan la necesidad de pasar desde una concepción más bien jurídica a una más bien pastoral de la institución parroquial y desde un rol exclusivo del clero en la tarea evangelizadora al reconocimiento de la comunidad y al incentivo de la corresponsabilidad de todos los bautizados en el anuncio del Evangelio. El último documento de la Conferencia del Episcopado Latinoamericano, el Documento conclusivo de la Conferencia General del Episcopado Latinoamericano reunido en Aparecida (Brasil), del año 2007, hace importantes afirmaciones sobre la parroquia. Por un lado, reconoce que debido a los distintos factores sociales, culturales y eclesiales ella encuentra cada vez más dificultades de comprensión que afectan directamente el cumplimiento de su misión, por lo que dirá, por otro lado, que la parroquia es "casa y escuela de comunión" (DA 170), "el lugar privilegiado en el que la mayoría de los fieles tiene una experiencia de Cristo y de comunión eclesial” (DA 170).

Como síntesis de los documentos anteriores podemos señalar que la parroquia es lugar de encuentro y envío, una comunidad eminente entre todas las demás comunidades; lugar y comunidad en donde el fiel se reconoce parte de la Iglesia y sujeto de la misión. La parroquia, por lo mismo, no es principalmente ni una estructura organizativa ni un territorio a gobernar, ni menos solo un templo. Es, en primer lugar, una comunidad de fieles unidos entre sí por la fe y la misión. La parroquia, finalmente, debe ser expresión de una unión y una interacción dinámica de las distintas categorías de fieles que la constituyen como una comunidad determinada de fieles bajo el cuidado pastoral de un mismo pastor.

4. XiII Asamblea General Ordinaria del Sínodo de los Obispos: LA PARROQUia, LUGAR TEOLÓGICO DE ESPIRITUALIDAD Y COMPROMISO APOSTÓLICO

Fuente importante de nuestra reflexión es la documentación, recientemente publicada, de la XIII Asamblea General Ordinaria del Sínodo de los Obispos sobre el tema "La Nueva Evangelización para la transmisión de la fe cristiana". Esta es, según los Lineamenta (Lin.), una expresión 
del "esfuerzo de renovación que la Iglesia está llamada a hacer para estar a la altura de los desafíos que el contexto sociocultural actual pone a la fe cristiana" (Lin. 5) ${ }^{20}$. Este documento se estructura desde dos realidades: La Nueva Evangelización y la Fe. Ambas son, en relación a la parroquia, los conceptos teológico-jurídicos que estructuran todo el desarrollo de este artículo $^{21}$. El documento describe una imagen clara y propone una estructura organizacional dinámica de la parroquia ${ }^{22}$.

La Nueva Evangelización recuerda a la parroquia que su actividad pastoral y su estructura administrativa están destinadas a la misión. En

20 En los Lineamenta, que tienen por finalidad suscitar el debate sobre el tema sinodal en el ámbito de la Iglesia universal y quieren ayudar a las Iglesias locales a reflexionar sobre los aspectos positivos, pero también sobre los mencionados desafíos y dificultades en la transmisión de la fe, se señala que Desde el punto de vista eclesiológico, es preciso reafirmar que la evangelización atañe a la naturaleza misma de la Iglesia, asi como a toda su actividad. Por lo tanto, el anuncio del Evangelio no es cuestión de estrategias de comunicación o de elección de destinatarios prioritarios, como podrían ser los jóvenes. Concierne a la capacidad de la Iglesia de configurarse "como real comunidad, como verdadera fraternidad, como un cuerpo y no como una máquina o una empresa” (Lineamenta 2). Mons. Eterovic afirma en su Relación que "De hecho, toda la Iglesia es misionera por naturaleza. Existe para evangelizar. Para cumplir esa tarea de modo adecuado, la Iglesia comienza evangelizándose a sí misma. No solo se reconoce como agente, sino también como fruto de la evangelización, convencida de que el protagonista principal es Dios, que la guía en la historia por medio del Espíritu de su Hijo unigénito, Jesucristo. La evangelización, por tanto, requiere una acción de discernimiento. La Iglesia, en su conjunto, está llamada a la escucha, a la comprensión, a la revisión y a la revitalización de su mandato evangelizador, especialmente frente a los grandes cambios del mundo contemporáneo". Disponible en: <http://www.vatican.va/roman_curia/synod/documents/ rc_synod_doc_20110304_lineamenta-xiii-assembly-conf_sp.html>

21 Importantes elementos interpretativos de este Sínodo lo constituyen distintos acontecimientos eclesiásticos, pasados y presentes. Durante su desarrollo se celebra, en efecto, el quincuagésimo aniversario de la apertura del Concilio Ecuménico Vaticano II, el vigésimo aniversario de la publicación del Catecismo de la Iglesia Católica y se abre el Año de la Fe, convocado por el papa Benedicto XVI.

22 El deber de anunciar la verdad salvífica no es solo responsabilidad del clero y los religiosos. Al contrario, este Sínodo ha resaltado el importante papel de cada discípulo de Cristo en la misión de transmitir la fe. El debate ha acentuado esta participación crucial y vital de todo católico a la misión evangelizadora, sobre todo mediante la participación solícita y los dones de los fieles laicos. Cf. CARD. Donald William Wuerl, Relatio post disceptationem, 1. Disponible en: <http:// www.vatican.va/news_services/press/sinodo/documents/bollettino_25_xiii-ordinaria-2012/04_spagnolo/b21_04.html> 
esta línea el documento de trabajo (Instrumentum laboris) ${ }^{23}$ sitúa la parroquia de una manera creativa "[...] al centro de la Nueva Evangelización [...]", y, considerada como comunidad de comunidades, es el punto de referencia y de coordinación eclesial de una vasta gama de otras realidades e iniciativas pastorales (IL 107). Con una magnífica descripción va a señalar que la parroquia es la Iglesia, "que vive entre las casas de sus hijos y de sus hijas" (IL 83) ${ }^{24}$. Al ser ella un espacio privilegiado para tener experiencias de comunión en la misión ${ }^{25}$, le corresponde un particular rol en la transmisión de la fe (IL 167) ${ }^{26}$. Pero esto que señalan en el aula sinodal podría quedar en el papel si ella misma no acepta este desafío, posibilitando en su interior una renovada experiencia comunitaria de la fe, a través de nuevas actividades pastorales, programas e iniciativas evangelizadoras en las que se vean involucradas la riqueza y la variedad de las personas, carismas y ministerios que la componen y de las comunidades, movimientos e institutos de vida consagrada y sociedades de vida apostólica que la animan ${ }^{27}$. No olvidemos que la Nueva Evangelización, si de verdad quiere ser nueva, debe ser un evento comu-

23 Documento que es resultado de todas las respuestas que hicieron llegar a los $\mathrm{Li}$ neamenta por parte de 13 Sínodos de Obispos de las Iglesias orientales católicas sui iuris, de 114 Conferencias episcopales, 26 Dicasterios de la Curia Romana y de la Unión de Superiores Generales, algunos laicos y otras instancias eclesiales.

24 IL 81: "En esta línea se espera mucho de las parroquias, consideradas como la puerta más capilar de ingreso en la fe cristiana y en la experiencia eclesial [...] son las primeras comunidades en las cuales se experimenta la alegría de ser congregados por el Espíritu y preparados para vivir el propio mandato misionero".

25 Es lo que lleva al cuerpo episcopal reunido a afirmar en el Mensaje Final al Pueblo de Dios, que ante este desafío "Hemos de constituir comunidades acogedoras, en las cuales todos los marginados se encuentren como en su casa, con experiencias concretas de comunión”. Sínodo de Obispos de la XIII Asamblea General Ordinaria, Mensaje Conclusivo, 3. [Fecha de consulta: marzo de 2013]. Disponible en: <http://www.vatican.va/news_services/press/sinodo/documents/bollettino_25_xiii -ordinaria-2012/04_spagnolo/b30_04.html>

26 R. S. Schevchuk, Arzobispo Mayor de Kyiv-Halyč, Jefe del Sínodo de la Iglesia Greco-Católica de Ucrania. Disponible en: <http://www.vatican.va/news_services/press/sinodo/documents/bollettino_25_xiii-ordinaria-2012/04_spagnolo/ b12_04.html>.

27 Cf. Sínodo de Obispos de la XIII Asamblea General Ordinaria, Relación de los Círculos Menores Anglicus, R. P. Tartaglia, Arzobispo de Glasgow. Disponible en: <http:/www.vatican.va/news_services/press/sinodo/documents/bollettino_25_ xiii-ordinaria-2012/04_spagnolo/b23_04.html> 
nitario en el cual participen personas, comunidades eclesiales de base, pequeñas comunidades y unidades pastorales ${ }^{28}$.

Desde estos parámetros, considerada como la puerta más capilar de ingreso en la fe cristiana y de la experiencia eclesial de cada bautizado, la parroquia va a ser el modo y el espacio eclesial más adecuado para realizar la Nueva Evangelización. Esta propuesta trajo como consecuencia que en el aula sinodal se insistiera en considerar la parroquia como el centro de la renovación de la Iglesia y centro vivo de evangelización ${ }^{29}$.

"Ellas son lugares en los cuales se educa en la búsqueda de la verdad, se nutre y se refuerza la propia fe; constituyen puntos de comunicación del mensaje cristiano, del designio de Dios sobre el hombre y sobre el mundo; son las primeras comunidades en las cuales se experimenta la alegría de ser congregados por el Espíritu y preparados para vivir el propio mandato misionero" 30 .

Este desafío de renovación de la experiencia comunitaria de la fe por medio de la evangelización, impulsa y exige que la parroquia cree instancias, estructuras y actividades capaces de sostener mejor la fe de sus miembros (IL 80), abandonando su clericalismo y su autorreferencialidad. En cada una de sus actividades, ella debería no solo acoger y servir a sus fieles, sino también animarlos y formarlos para que sean agentes y protagonistas excelsos de la Nueva Evangelización, sobre todo en la dispersión de las grandes metrópolis. Esta fisonomía parroquial exige que su forma de gobierno refleje a una parroquia que se realiza desde la cooperación misionera y comunitaria, donde todos estén más comprometidos y participen y colaboren en el trabajo de evangelización con nuevo ardor, método y expresión (IL 80).

28 Como afirma Benedicto XVI en la homilía de inauguración del Sínodo de los Obispos XIII Asamblea ordinaria: "Esta temática responde a una orientación programática para la vida de la Iglesia, la de todos sus miembros, las familias, las comunidades, la de sus instituciones". Disponible en: <http://www.vatican.va/news_services/press/sinodo/documents/bollettino_25_xiii-ordinaria-2012/04_spagnolo/ b03_04.html>

29 Cf. Sínodo de Obispos de la XIII Asamblea General Ordinaria, Proposición 44, en FinAl List of Propositions. Disponible en: <http://www.vatican.va/news_ services/press/sinodo/documents/bollettino_25_xiii-ordinaria-012/02_inglese/ b33_02.html>

30 Sínodo de Obispos de la XIII Asamblea General Ordinaria, Instrumentum laboris, 81. 
La asamblea sinodal enfatiza, de este modo, el profundo cambio hermenéutico que la Nueva Evangelización, en el Año de la Fe, le plantea a la parroquia. La Nueva Evangelización deberá operar, entonces, una transformación teológica y pastoral en la comprensión del ser y hacer de la parroquia. De una comunidad clerical se debe pasar a una comunidad de fieles, de una comunidad de colaboración a una comunidad de participación, de una comunidad de servicios a una comunidad de envío. Lo anterior exige que ellas dejen de ser solo centros de servicios cultuales y administrativos para llegar a ser casas de la comunidad de cristianos y escuelas de discípulos misioneros; constituyéndola, por estos cambios, en un espacio apropiado y favorable para el ejercicio del ministerio de la Palabra de cada uno de sus miembros bajo la presidencia y autoridad del párroco, que le permita resituarse como el lugar privilegiado de la experiencia comunitaria de la fe y el anuncio ${ }^{31}$. Si no se realiza tal cambio de óptica, seguiremos dando la impresión de que la parroquia es una institución obsoleta, una institución administradora de servicios y sacramentos, cerrada en sí misma, y no una institución válida en la misión evangelizadora, una comunidad apostólica abierta, constituida por discípulos evangelizadores ${ }^{32}$. Fruto de esta transformación teológicojurídica de la parroquia debería actuarse una renovación pastoral en las

31 Una diócesis italiana, Rovigo, va a captar anteriormente esta intencionalidad del Sínodo y va a señalar que la parroquia debe transformarse "Da comunità clericale a comunità di partecipazione. E' necessario che la comunità diventi sempre di più luogo di partecipazione responsabile, dove tutti sono stimolati a diventare adulti, attivi e responsabili (cf. Ef 4, 11-16), e dove ogni operatore pastorale aiuta gli altri battezzati a svolgere il proprio servizio, secondo i propri carismi. Da comunità chiusa in se stessa a comunità in missione. E' necessario mettere le parrocchie in missione, al servizio del Regno. Parrocchia e Nuova Evangelizzazione alla luce degli Orientamenti pastorali della CEI "Comunicare il Vangelo in un mondo che cambia", Diocesi di Adria-Rovigo, Rovigo, 9 dicembre 2006, pags. 4-5. Disponible en: <http://www.diocesi.rovigo. it/omelie/anno2004/parrocchia-evangel-091204.pdf>

32 La Nueva Evangelización pasa por una parroquia de rostro nuevo, capaz de acompañar en la fe y en el mundo personal y afectivo a la gente, de lo que más se carece hoy en nuestra sociedad. Las parroquias debieran ser una red de comunidades eclesiales que, en sus concretos contextos, sustenten la fe en Cristo Jesús y su seguimiento y, por lo mismo, el crecimiento en la dimensión humana integral. Estos cuerpos eclesiales (las parroquias y sus comunidades) son los llamados a mostrar al Señor resucitado, que da vida y sentido a la existencia. Quizás el problema más acuciante de la Nueva Evangelización es la constitución y acompañamiento de estas pequeñas comunidades eclesiales. Cf. S. Silva, Sinodo de los Obispos, XIII Asamblea General Ordinaria, Relación de los Círculos Menores Hispanicus. Disponible en: <http:// 
personas, comunidades, carismas y ministerios que la componen. Solo así se constituirá la parroquia en un lugar privilegiado para el anuncio de la Palabra ${ }^{33}$, porque la evangelización es un evento comunitario y eclesial, no es nunca individual y sectarios sino una actividad de la comunidad cristiana en su conjunto y de cada uno en particular ${ }^{34}$.

Realizar tal renovación exige, desde la Fe y la Evangelización, evitar que en su interior que tales procesos se transformen en simples procedimientos administrativos y burocráticos. Deben ser, por el contrario, procesos de gobierno pastoral que hagan de la parroquia una casa y escuela de comunión, un lugar eclesial de espiritualidad y apostolado, en donde se aprenda de la comunión y de la corresponsabilidad en la misión. A nivel pastoral, todo su hacer debería suscitar un renovado dinamismo misionero. Un programa pastoral bien preparado, bien debatido y bien decidido por los diferentes fieles, carismas y vocaciones dará ciertamente sus buenos frutos evangelizadores.

Para concluir este capítulo, en relación a las preguntas que nos ocupan, podemos establecer dos conclusiones: la primera, que desde la XIII Asamblea Ordinaria del Sínodo de los Obispos, podemos describir la parroquia como un espacio privilegiado de evangelización y apostolado, en el cual los fieles se reúnen para hacer crecer su fe y desde el cual participan en la misión de la Iglesia. A la luz de lo anterior, concluimos, también, que se debe reconocer que el sujeto de la Nueva Evangelización no es solo el párroco ni los demás fieles considerados individualmente, sino la parroquia en tanto sujeto único y unitario del anuncio de la Palabra ${ }^{35}$.

www.vatican.va/news_services/press/sinodo/documents/bollettino_25_xiii-ordinaria-2012/04_spagnolo/b24_04.html>.

33 "La parroquia es, además, lugar privilegiado del anuncio de la palabra de Dios. Este anuncio se articula en diversas formas, y cada fiel está llamado a participar activamente en él, de modo especial con el testimonio de la vida cristiana y la proclamación explícita del Evangelio, tanto a los no creyentes, para conducirlos a la fe, como a cuantos ya son creyentes, para instruirlos, confirmarlos e impulsarlos a una vida más fervorosa", en: Congregación para el Clero, Instrucción El Presbitero, 4.

34 Cf. B. Forte, Sinodo de los Obispos, XIII Asamblea General Ordinaria, Relación de los Círculos Menores Italicus B. Disponible en: <http://www.vatican.va/news_services/ press/sinodo/documents/bollettino_25_xiii-ordinaria-2012/04_spagnolo/ b23_04.html>

35 Señala Coccopalmerio que la parroquia es un sujeto unitario: "più persone sono unite tra loro e per tale motivo sono una sola realtà composta da più persone; in altre parole, 


\section{El párroco, Su misión de pastor de la Nueva Evangelización}

Lo anterior, el carácter comunitario de la parroquia, va a permitir que, gracias a la reflexión eclesiológica conciliar, el CIC/83 sitúe al párroco y su oficio desde la perspectiva de la parroquia y no al revés: se da un párroco al pueblo y no un pueblo al párroco ${ }^{36}$. Es en esta línea argumentativa que el Código vigente estructura y presenta la normativa acerca del párroco; lo principal no es en sí mismo su oficio, sino la finalidad del mismo: la cura pastoral de esa determinada communitas fidelium (can. $529 \$ 2)^{37}$. En el cumplimiento de la cura pastoral, él deberá preocuparse que los fieles bajo su cuidado tomen parte en las iniciativas que miren

sono un insieme (universitas; cf. cc. 114-115). Non sono due o cento, ma uno solo. Questo uno è il soggetto di cui sopra...", en F. Coccopalmerio, "Il parroco» "pastore» della parrocchia”, en QDE, 4(1993), 15. Concluye su excelente artículo Mons. Coccopalmerio con las siguientes afirmaciones: Pertanto nella nostra visione soggetto di azione ecclesiale, in ultima e più profonda istanza, non sono né il parroco né gli altri fedeli intesi come singoli, ma è la parrocchia stessa intesa come comunità, come soggetto unitario. In questo senso, possiamo ricorrere anche al c. 515, par. 3, dove si afferma che la parrocchia è persona giuridica: orbene la parrocchia, in quanto è persona giuridica, è precisamente soggetto unitario ed è soggetto che agisce per l'attuazione delle finalità che le sono proprie, en F. Coccopalmerio, "Il parroco...", 21.

36 "Parochum dari populo non populum parocho", citado en A. MarzoA, "La figura del párroco: su estatuto jurídico", en La Parroquia desde el nuevo Derecho Canónico (Salamanca 1991), 31.

37 Es conveniente recordar, en este sentido, lo que establece Juan Pablo II en la Exh. ap. Ecclesia in America, cuando afirma que si se quiere renovar la parroquia hay que renovar la figura del párroco. Lo que: “[...] supone [...] que, en primer lugar, tenga una profunda experiencia de Cristo vivo, espíritu misional, corazón paterno, que sea animador de la vida espiritual y evangelizador capaz de promover la participación. La parroquia renovada requiere la cooperación de los laicos, un animador de la acción pastoral y la capacidad del pastor para trabajar con otros”. Cf. JuAN PABLo II, Ecclesia in America: Exhortación apostólica, 41. El mismo Pontífice afirma que no solo el párroco, sino también la misma parroquia debe renovarse en su forma de auto comprenderse cuando establece que las parroquias están llamadas a ser receptivas y solidarias, lugar de la iniciación cristiana, de la educación y la celebración de la fe, abiertas a la diversidad de carismas, servicios y ministerios, organizadas de modo comunitario y responsable, integradoras de los movimientos de apostolado ya existentes, atentas a la diversidad cultural de sus habitantes, abiertas a los proyectos pastorales y superparroquiales y a las realidades circunstantes.

En la misma línea, la Congregación para el clero establece que para servir a la Iglesia -comunidad orgánicamente estructurada por fieles dotados de la misma dignidad bautismal, pero con carismas y funciones diversa- es necesario conocerla y amarla, Cf. Congregación para el Clero, Instrucción El Presbitero, 16. 
a fomentar esa comunión y la consoliden para que cada uno descubra aquella parte que le corresponde en el anuncio dinámico del Evangelio ${ }^{38}$.

En este contexto eclesial, la parroquia de rostro misionero, nos preguntamos: ¿Cuál es y en qué consiste la actividad del párroco en la realización de la Nueva Evangelización? ¿Es la suya una actividad administrativa o una función ministerial de servicio evangelizador? ${ }^{39}$.

El párroco, en el ejercicio de su autoridad ministerial, debe tener presente aquello que es la parroquia: una determinada comunidad de fieles encomendada a su cuidado pastoral que se debe constituir en un lugar privilegiado para el anuncio de la Palabra, en el que cada uno de los miembros y asociaciones parroquiales reconozcan y asuman la parte que les compete en tal misión (can. $529 \$ 2)^{40}$. El fundamento teológico-jurídico de esta afirmación, como lo veremos a continuación, no es primeramente jurídico, sino sacramental (cann. 96; 204; 211; 781) ${ }^{41}$.

Si bien es a partir de la proclamación del Evangelio que la Iglesia se edifica como comunidad, como creatura Verbi (AG 37) ${ }^{42}$, este anun-

38 El ministerio de los presbíteros es, ante todo, de comunión y colaboración responsable y necesaria y está totalmente al servicio de la Iglesia; está para la promoción del ejercicio del sacerdocio común de todo el Pueblo de Dios; el presbítero está ordenado no solo para la Iglesia particular, sino también para la Iglesia universal $(\mathrm{PO}, 10)$. Su tarea, por lo tanto, es procurar que todos cumplan el papel propio.

F. Coccopalmerio, "Il párroco...", 8.

40 "Toda la vida de la parroquia, así como el significado de sus tareas apostólicas ante la sociedad, deben ser entendidos y vividos con un sentido de comunión orgánica entre el sacerdocio común y el sacerdocio ministerial, y por tanto, de colaboración fraterna y dinámica entre pastores y fieles en el más absoluto respeto de los derechos, deberes y funciones ajenos, donde cada uno tiene sus propias competencias y su propia responsabilidad" en: Congregación para el Clero, Instrucción El Presbitero, 18.

41 Cf. A. Montan, "La funzione di insegnare della Chiesa”, en C. Cappelleni (ed). La normativa del nuovo Codice (Brescia, 19852) 147-175; íd. "Il Libro III. La funzione di insegnare della Chiesa», en ScCatt. 112 (1984) 252-277, También en A. URRU, La funzione di insegnare (Roma 20012).

42 Las raíces de la proclamación de la Buena Nueva están en la comunión (koinonia) y también en el servicio (diakonia). Tanto el Motu proprio Porta Fidei (n. 14) como el Instrumentum laboris de este Sínodo (n. 123) recuerdan que la fe y la caridad están vinculadas la una a la otra. La relación intrínseca entre evangelización y diakonia. Cf. S. Em. R. Card. Robert Sarah, Presidente del Pontificio Consejo Cor Unum. Disponible en: <http://www.vatican.va/news_services/press/sinodo/documents/bollettino_25_xiii-ordinaria-2012/04_spagnolo/b12_04.html> 
cio no se puede realizar de cualquier manera. Esta obligación pastoraljurídica del párroco la reafirma el Mensaje Final de la XIII Asamblea General Ordinaria del Sínodo de Obispos:

"Junto a los sacerdotes reconocemos la presencia de los diáconos así como la acción pastoral de los catequistas y de tantas figuras ministeriales y de animación en el campo del anuncio y de la catequesis, de la vida litúrgica, del servicio caritativo, así como las diversas formas de participación y de corresponsabilidad de parte de los fieles" ${ }^{\text {43. }}$.

Por esto es que la Nueva Evangelización recuerda la responsabilidad que les cabe a todos en la realización del mandato misionero de Jesús (individuos, comunidades, parroquias, diócesis, conferencias episcopales, movimientos, grupos y otras realidades eclesiales, religiosos y personas consagradas $)^{44}$. En el ejercicio pleno de su autoridad pastoral, el párroco deberá fomentar en los bautizados una mayor conciencia acerca de la responsabilidad misionera y evangelizadora que les corresponde. Mediante el ejercicio de su cura pastoral, deberá facilitar aquello que todos los fieles cristianos necesitan para ser conscientes de que son partícipes de la misión de Cristo y auténticos agentes de la Nueva Evangelización (can. $529 \$ 2$ y AG 37) ${ }^{45}$.

Si anteriormente hemos señalado que la parroquia no es una estación de servicios sacramentales, ni menos una mera institución administrativa de la Iglesia que se constituye a partir del párroco, es válido afirmar que la potestad propia y ordinaria del párroco es un precioso instrumento de comunión con su obispo, los demás presbíteros, diáconos, religiosos, religiosas, laicos y laicas; es decir, un instrumento y fundamento de

43 Cf. Sínodo de Obispos de la XIII Asamblea General Ordinaria, Mensaje Final, 8. Disponible en: <http://www.vatican.va/news_services/press/sinodo/documents/bollettino_25_xiii-ordinaria-2012/04_spagnolo/b30_04.html>

44 Cf. Sínodo de Obispos de la XIII Asamblea General Ordinaria, Instrumentum Laboris, 77.

45 Las raíces de la proclamación de la Buena Nueva están en la comunión (koinonia) y también en el servicio (diakonia). Tanto el Motu proprio Porta Fidei (n. 14) como el Instrumentum laboris de este Sínodo (n. 123) recuerdan que la fe y la caridad están vinculadas la una a la otra. La relación intrínseca entre evangelización y diakonia. Cf. S. Em. R. Card. Robert Sarah, Presidente del Pontificio Consejo "Cor Unum». Disponible en: <http://www.vatican.va/news_services/press/sinodo/ documents/bollettino_25_xiii-ordinaria-2012/04_spagnolo/b12_04.html> 
comunión con esa particular comunidad de fieles que se le ha encomendado a su cuidado pastoral (DA 199) ${ }^{46}$.

Específicamente, el párroco está sacramental y jurídicamente capacitado para ser, en el plano pastoral, el pastor de la comunión, de la guía y del servicio; el hombre de la misión y del diálogo, de manera que aparezca claramente que la parroquia es una comunidad orgánica de fieles; es decir, que se caracteriza por la simultánea presencia de la diversidad y unidad, diferenciación y complementariedad de vocaciones y condiciones de vida, de ministerios y carismas y de obligaciones y responsabilidades (Chf. 26) ${ }^{47}$. Gracias a la autoridad jurídica del párroco, acompañada de su autoridad moral, toda la parroquia se sentirá estimulada para profundizar y realizar su actividad misionera sea ad intra sea ad extra, de modo menos clerical e individualista, más abierto al trabajo en equipos y consejos, de manera orgánica y comunional ${ }^{48}$. Como constructor de la comunidad deberá, en el ejercicio de su autoridad, presidir la participación y la colaboración, reconociendo las personas y los carismas e integrándolos en una pastoral de conjunto $(\mathrm{PO} 6)^{49}$.

El CIC/83 establece que lo constitutivo de la parroquia es la actividad conjunta, jerárquica y orgánica de todos los fieles que la constituyen $^{50}$, y que el párroco es quien la conserva y anima en la communio

46 Cf. Juan Pablo II, Audiencia del 19 Mayo 1993: Insegnamenti XVI, 1 (1993) 1254.El fin esencial de la cura pastoral que le es propia y de la autoridad pastoral con la cual ha sido investido es el de conducir a un pleno desarrollo de vida espiritual y eclesial la comunidad que se le ha encomendado mediante el ejercicio del ministerio de la Palabra.

47 Cf. Juan Pablo II, Pastores dabo bobis: Exhortación posinodal, 18. Ver, además, Juan PABlo II, "Discorso alla Congregazione Plenaria della Congregazione per il Clero", en Insegnamenti (1984), 984-985. La importancia jurídica del aspecto comunitario del ministerio del sacerdote se manifiesta en los cann. $245, \$ 2 ; 495, \$ 1 ; 499 ; 529$, $\$ 2 ; 713, \$ 3 ; 757$. Cf. G.F. Mariconti, “Il Parroco...”, 250.

El párroco debería conseguir que las distintas vocaciones y carismas, personales y comunitarios, las asociaciones, movimientos y agrupaciones presentes en la parroquia tengan el espacio adecuado para ofrecer su específica contribución con respecto a la función de anunciar el Evangelio, de modo que la parroquia aparezca ya no como un centro de servicios sacramentales, sino como un claro ejemplo de apostolado comunitario.

50 Quienes colaboran en la actividad parroquial, se reúnen en unidad y toman parte activa, cada uno según su modo propio, de acuerdo con la diversidad de carismas, funciones y ministerios. Ellos asumen y cumplen, con absoluta responsabilidad, los 
fidei, la communio sacramentorun, la communio disciplinae y la communio

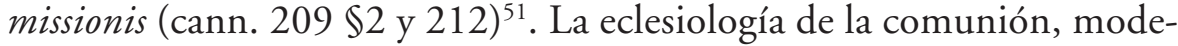
lo eclesiológico que fundamenta toda nuestra reflexión, compromete al párroco a construir no solo para otros, sino, especialmente, con otros, la comunidad parroquial ${ }^{52}$.

\section{Los desafíos de la Nueva Evangelización a la parroquia}

Hemos señalado en las páginas anteriores que, por un lado, evangelizar es una acción fundamental de la Iglesia, que estructura su rostro, sus acciones y manifiesta su identidad ${ }^{53}$; por otro, que el mandato del anuncio y de la proclamación de la Palabra de Dios que Cristo encomendó a la Iglesia, no está reservado al párroco o a algunos en particular dentro de la parroquia, sino que es un don ofrecido a cada hombre que responde confiadamente a la llamada de fe. Evangelizar es la experiencia de cada cristiano y de toda la Iglesia ${ }^{54}$.

Dos preguntas nos ayudan a explicar este título: ¿Cómo se pueden fomentar y coordinar en la parroquia las iniciativas pastorales para la Nueva Evangelización? ¿Cómo se puede generar una mejor organización pastoral en la parroquia para que los laicos -hombres y mujeres- parti-

compromisos apostólicos según su propia condición, cuidando siempre de trabajar de común acuerdo con el párroco y en armonía con los otros responsables. Cf. Congregación para los Obispos, en el Directorio para el Ministerio Pastoral de los Obispos, n. 211.

51 Cf. G.F. Mariconti, "Il Parroco...", 245-256

52 Es lo que reafirma la Novo Millennio ineunte 43: "Antes de programar iniciativas concretas, hace falta promover una espiritualidad de la comunión, proponiéndola como principio educativo en todos los lugares donde se forma el hombre y el cristiano, donde se educan los ministros del altar, las personas consagradas y los agentes pastorales, donde se construyen las familias y las comunidades". JuAN Pablo II, NMI, 06-01-2001.

53 Cf. Sínodo de Obispos de la XIII Asamblea General Ordinaria, Lin.12.

54 Como afirma la XIII Asamblea General Ordinaria del Sínodo de los Obispos, «esta tarea de anuncio y proclamación no está reservada solo a algunos ni a pocos elegidos. Es un don hecho a cada hombre que responde a la llamada de la fe» (IL 92). No es una acción especializada, que pueda ser adjudicada a algún grupo o a individuo expresamente designado 
cipen junto al párroco en el ministerio de la Palabra, que es constitutivo de la evangelización? ${ }^{25}$.

Ante este desafío de la Nueva Evangelización, la parroquia debe buscar y encontrar nuevos métodos y formas de vivificar sus existentes estructuras de gobierno para encontrar una nueva organización y preparar nuevos evangelizadores para estar a la altura de las necesidades del hombre contemporáneo y de las expectativas de la sociedad ${ }^{56}$. En la ejecución de esta misión comunitaria, el párroco promoverá un cambio radical de actitudes de pertenencia, una verdadera conversión pastoral en cada uno de los fieles parroquiales ${ }^{57}$. De este modo llevará a su comunidad parroquial a un estado de misión permanente, consagrando todas sus fuerzas y recursos para que el Kerigma, la catequesis, la vida de comunidad (koinonia) y la solidaridad (diakonia) sean principios estructuradores de su hacer.

En este proceso de relanzamiento de la misión fundamental de la Iglesia, el párroco debería crear las condiciones eclesiales necesarias para que todos los fieles encomendados a su cura pastoral se consoliden en su identidad cristiana, viviendo y anunciando el Evangelio ${ }^{58}$. Está claro, entonces, que en este campo del ejercicio del ministerio de la Palabra, es indispensable la reciprocidad. Esta reciprocidad se manifiesta en la cooperación y colaboración de todos los miembros de la comunidad parroquial en cuanto comunidad de discípulos y misioneros de Jesucristo (DA 172) ${ }^{59}$. Este es el criterio de la actual hermenéutica de la renovación parroquial ${ }^{60}$.

55 Es lo que exige la Congregación para el clero cuando afirma que: "La nueva evangelización pide un ardiente ministerio de la Palabra, integral y bien fundado, con un claro contenido teológico, espiritual, litúrgico y moral, atento a satisfacer las concretas necesidades de los hombres", Congregación para el Clero, Instrucción El Presbitero, 2.

56 "La misión renueva la Iglesia, refuerza la fe y la identidad cristiana, da nuevo entusiasmo y nuevas motivaciones. ¡La fe se fortalece dándola!”, Juan Pablo II, Carta Encíclica Redemptoris missio (7 de diciembre de 1990), 2: AAS 83 (1991) 251.

57 "El empeño ardientemente misionero a favor de la evangelización tiene una especial prioridad para la Iglesia, y por consiguiente para la pastoral parroquial”. Cf. Pablo VI, Exhort. Ap. Evangelii Nuntiandi, 14. Consultar también en ConferenCia episcopal italiana, Nota Pastorale Il volto missionario, 5. Cf. J. M. Diaz, Derechos, 26-131.

59 Cf. Congregación para la evangelización de los pueblos, Guía pastoral para los sacerdotes diocesanos de las Iglesias que dependen de la Congregación para la Evangelización de los Pueblos (Roma 1989), 7.

60 Benedicto XVI, Discurso a la Curia Romana con ocasión de las felicitaciones navideñas (22 de diciembre de 2005): AAS 98 (2006) 46. 
Entonces, será especial preocupación del párroco conseguir que las distintas asociaciones, movimientos y agrupaciones presentes en la parroquia, junto a las pequeñas comunidades de base o unidades pastorales, ofrezcan su específica contribución en el anuncio del Evangelio ${ }^{61}$. Gracias a la hermenéutica de la reciprocidad parroquial, el párroco deberá, como una especial obligación suya, urgir para que también otros anuncien la palabra de Dios (can. 767); organizar predicaciones extraordinarias (can. 770); preocuparse de la evangelización y catequesis de los marginados y no creyentes (can. 771), de la formación catequética de los adultos, jóvenes y niños (can. 776), de la catequesis familiar (can. 774), de impulsar a los laicos a perfeccionar el orden de las realidades temporales con el espíritu evangélico (can. 225), a instituir en la parroquia una mejor y mayor estabilidad, visibilidad ministerial y formación a todos aquellos que se dedican de manera estable a actividades del ministerio de la Palabra. De manera particular, el párroco sabrá suscitar la justa y oportuna colaboración y responsabilidad -en lo referente a la catequesis- de los miembros de institutos de vida consagrada o sociedades de vida apostólica, de movimientos y asociaciones. Así cumplirá, atenta y fraternalmente, el deber de ejercer una cuidadosa y primorosa vigilancia sobre todos y cada uno de sus colaboradores ${ }^{62}$, añadiendo la tarea de garantizar y coordinar el anuncio y enseñanza recta, completa y eficaz del mensaje cristiano.

La Nueva Evangelización, este es su desafío, empeña a todos los sujetos parroquiales ${ }^{63}$. En el ejercicio de su potestad de gobierno, el párroco

${ }^{61}$ Creo importante para el objetivo de nuestro artículo tener presente lo que afirma el Documento final de la V Asamblea General del Episcopado Latinoamericano, sobre las comunidades eclesiales de base en sus nn.178-179.

62 "Aunque es verdad que se puede catequizar en todas partes, quiero subrayar -conforme al deseo de muchísimos obispos- que la comunidad parroquial debe seguir siendo la animadora de la catequesis y su lugar privilegiado". Juan Pablo II, Catechesi tradendae, 67.

63 El párroco llama a todos a profundizar y potenciar sus propias iniciativas y actividades pastorales, a través de la promoción de especiales carismas y ministerios: promueve en los presbíteros, diáconos y laicos la conciencia de la propia misión y a desarrollarla con libertad y responsabilidad, cultivando en sus miembros el deseo y la capacidad de la misión. "Toda la vida de la parroquia, así como el significado de sus tareas apostólicas ante la sociedad, deben ser entendidos y vividos con un sentido de comunión orgánica entre el sacerdocio común y el sacerdocio ministerial y, por tanto, de colaboración fraterna y dinámica entre pastores y fieles en el más 
deberá asumir, con responsabilidad ministerial y autoridad moral, primera y principalmente, actitudes interiores y exteriores que signifiquen reconocimiento y promoción de la corresponsabilidad que es propia de la naturaleza ministerial de los derechos y deberes de los demás fieles en la parroquia y de la Iglesia particular a la cual pertenece (cann. $529 \$ 2$; $275 \$ 2$; PO 9 ${ }^{64}$. Gracias a esta responsabilidad ministerial del párroco, la parroquia podrá vivir plenamente su fe como agente auténtica y eficaz de la inculturación del Evangelio en la realización de la Nueva Evangelización ${ }^{65}$, de la cual él no es dueño, sino es deudor en relación al pueblo de Dios $^{66}$. Es lo que afirma el can. $528 \$ 1$, con las palabras providendi ut, con lo que señala que el párroco no debe realizar exclusivamente todas estas tareas, sino procurar que también los demás fieles, bajo su autoridad, colaboren, se integren y sean miembros activos en el anuncio del Evangelio, participando de manera oportuna, conforme a la recta doctrina y a la disciplina eclesial, según las circunstancias y bajo su autoridad. Si el párroco es promotor y animador de la comunidad misionera, deberá, por lo mismo, sensibilizar a su comunidad parroquial para que asuma el reto de la Nueva Evangelización, esforzándose por poner "al centro de la nueva evangelización la parroquia, comunidad de comunidades, no solo administradora de servicios religiosos, sino espacio para las familias, promotora de grupos de lectura de la Palabra y de un renovado compromiso laical, lugar en el cual se hace una verdadera experiencia de Iglesia, gracias a una acción sacramental vivida en su significado más genuino, permitiendo que en ella se adopte un estilo más misionero de la propia presencia dentro del tejido social" (IL 107). Lo anterior lleva al Episcopado Latinoamericano a afirmar que los párrocos deben ser "[...] promotores y animadores de la diversidad misionera... exigiendo nuevos ser-

absoluto respeto de los derechos, deberes y funciones ajenos, donde cada uno tiene sus propias competencias y su propia responsabilidad", en CONGREGACIÓN PARA EL CLERo, Instrucción El Presbitero, 18.

Sínodo de Obispos de la XIII Asamblea General Ordinaria, IL.66.

65 Afirma el Directorio Apostolorum successores n. 211, que la parroquia es: "[...] un excelente modo de existencia de la comunidad eclesial; un lugar teológico de encuentro y unidad de fieles, grupos, asociaciones y movimientos, en la cual están todos invitados a asumir decididamente la tarea misionera de la Iglesia, por medio de la colaboración presbiteral y participación de los fieles (clérigos, consagrados y laicos) en la actividad parroquial en la comunión eclesial vivida jerárquica y apostólicamente".

66 Juan Pablo II, Pastor Dabo vobis, del 25 de marzo de 1992, 26 b. 
vicios y ministerios en la realización de la comunión misionera" (DA 202). El párroco, presidiendo y reconociendo a su comunidad de fieles como sujeto unitario de la acción evangelizadora, estará obligado, por medio de su potestad ordinaria y propia, a procurar que la palabra de Dios se anuncie por quienes y a quienes viven en la parroquia y fuera de ella. Él es el que, en primer lugar, debe predicar el Evangelio de Dios a todos, pero también es su responsabilidad ministerial y canónica hacerlo junto a otros y con todos para constituir e incrementar el Pueblo de Dios. Por lo tanto, podemos decir que bajo su presidencia, necesaria y esencial, la parroquia anuncia la palabra de Dios y se constituye en agente apostólico imprescindible y compacto para realizar la Nueva Evangelización como sujeto, destinatario e interlocutor, de modo que la parroquia ofrezca un claro ejemplo de apostolado comunitario (AA 10) ${ }^{67}$. La parroquia, concebida a la luz de la Nueva Evangelización, estará menos orientada hacia el interior de sí misma y más comprometida con el anuncio de la fe hacia fuera, hacia las periferias de la existencia humana.

En esta línea se espera mucho de las parroquias, consideradas como la puerta más capilar de ingreso en la fe cristiana y en la experiencia eclesial, "[...] asumen el compromiso de ser verdaderos centros de irra-

67 Leemos en un documento parroquial de la Parroquia de la Divina Gracia que: La parroquia es Misionera cuando: 1) Realiza un proceso integral de evangelización en todos los niveles: Evangeliza con todo a todos en su comunidad; Realiza su servicio con un proceso que armoniza el anuncio del kerigma, la catequesis, la liturgia, el servicio de la caridad, la animación de la comunidad y el servicio misionero; evangeliza a todas las personas, las comunidades eclesiales; busca que sus feligreses y sus comunidades se comprometan como evangelizadores; evangeliza la cultura e incultura la fe. 2) Asume, organiza y realiza adecuadamente la pastoral misionera, integrándola como elemento primordial dentro de su pastoral ordinaria. 3) Organiza y realiza los tres servicios de la pastoral misionera: la animación misionera; la formación misionera; y la promoción de la cooperación misionera. 4) Ayuda a sus miembros. 5) Promueve las vocaciones misioneras. 6) Promueve pequeñas comunidades eclesiales. 7) Penetra las estructuras y organismos pastorales de la parroquia con espíritu misionero. 8) Realiza, con énfasis misionero, dentro de la comunidad local, las acciones pastorales, saliendo a buscar a los más necesitados. 9) Dinamiza la comunión y participación evangelizadoras dentro de la parroquia. 10) Integra y forma un comité parroquial de misiones. 11) Organiza y anima los servicios y grupos. 12) Asigna suficiente recursos materiales para la pastoral misionera parroquial. 13) La parroquia es misionera cuando evangeliza, también, más allá de sus fronteras. [Fecha de consulta: marzo de 2013]. Disponible en: <http://www.parroquiamadredeladivinagracia.org/adviento/haciaunaparroquiamisionera.pdf> 
diación y de testimonio de la experiencia cristiana, [...]; son las primeras comunidades en las cuales se experimenta la alegría de ser congregados por el Espíritu y preparados para vivir el propio mandato misionero" ${ }^{36}$. Solo así se podrá estar en presencia de una estructura misionera en la parroquia que busca organizar su actividad desde un real protagonismo pastoral de todos los fieles unidos en una trama de relaciones misioneras y apostólicas ${ }^{69}$. Este es el mejor medio, el Evangelio, para que se construya la comunidad parroquial de fieles y se ayude al crecimiento de una auténtica comunión eclesial (PO 9, can. $275 \$ 2)^{70}$, en la cual cada uno de los fieles, elegidos y preparados convenientemente, de acuerdo a su propio estado y condición, entren en contacto con la palabra de Dios y a ella sirvan, para que tomen conciencia de la responsabilidad que les compete en la Iglesia, descubran su propia vocación y misión y actúen los derechos y deberes que les exige la misma misión (LG 30 ${ }^{71}$. Se tratará, entonces, de promover en el párroco, y en esta particular comunidad de fieles, una mentalidad y una actitud ministerial, como el mejor modo para que la parroquia crezca en la comunión ad intra y en la comunión ad extra gracias al anuncio del Evangelio ${ }^{72}$.

68 Sínodo de Obispos de la XiII Asamblea General Ordinaria, IL 81.

69 Congregación para el Clero, Instrucción El Presbitero, 20.

70 La Chiesa è casa, edificio, dimora ospitale che va costruita mediante l'educazione a una spiritualità di comunione... Soltanto se sarà davvero "casa di comunione", resa salda dal Signore e dalla Parola della sua grazia, che ha il potere di edificare (cf. At 20, 32), la Chiesa potrà diventare anche "scuola di comunione" en CONFERENCIA EPISCOPAL italiana, Orientamenti pastorali: "Comunicare il Vangelo in un mondo che cambia", per guidare il cammino delle nostre comunità nel primo decennio degli anni 2000, n. 65.

71 Afirma el DA en su n. 203 que: "Una parroquia, comunidad de discípulos misioneros, requiere organismos que superen cualquier clase de burocracia. Los Consejos Pastorales Parroquiales tendrán que estar formados por discípulos misioneros constantemente preocupados por llegar a todos. El Consejo de Asuntos Económicos, junto a toda la comunidad parroquial, trabajará para obtener los recursos necesarios, de manera que la misión avance y se haga realidad en todos los ambientes. Estos y todos los organismos han de estar animados por una espiritualidad de comunión misionera: Sin este camino espiritual de poco servirían los instrumentos externos de la comunión. Se convertirían en medios sin alma, máscaras de comunión más que sus modos de expresión y crecimiento”.

72 Creo que para promover esta nueva actitud ministerial en el íntegro anuncio del Evangelio, el párroco deberá realizar en su persona y ministerio, como, también, en su comunidad parroquial, la necesaria conversión eclesiológica que exige el CVII y los últimos documentos de la Iglesia, los que manifiestan que la Iglesia es una 


\section{Conclusión}

En estas páginas, desde una reflexión teológica en el contexto del Año de la Fe y a la luz de las sugerencias que ha ofrecido la XIII Asamblea General Ordinaria del Sínodo de los Obispos sobre la Nueva Evangelización para la transmisión de la fe cristiana, hemos explicitado que existen parroquias en las cuales las estructuras y estilos pastorales no siempre ayudan a afrontar con éxito el desafío misionero que tienen por delante.

Si no se toma en serio la íntima relación que existe entre la palabra de Dios y la misión de la Iglesia, como el esfuerzo de favorecer el encuentro de cada ser humano con la palabra de Dios, la Nueva Evangelización corre el riesgo de no ser el hecho eclesial de comunión en la misión.

La llamada Nueva Evangelización, en cambio, recuerda que la parroquia, y, en ella, el párroco, existen para proveer al cuidado pastoral de los fieles y para la realización del mandato misionero que Jesús encomendó a su Iglesia. Lo que pretende esta propuesta eclesiológica, programática y paradigmática, es poner en clave misionera el hacer de la parroquia, para que ella se replantee su verdadero significado a la luz del ejercicio del ministerio de la palabra de Dios. Habiendo sido congregada por la palabra de Dios, es, simultáneamente, una comunidad de fe y una comunidad evangelizadora, un lugar en donde los fieles forman parte pero a la vez desde donde deben salir. La Nueva Evangelización quiere reavivar en la parroquia toda una dinámica de reforma de las estructuras eclesiales como consecuencia de la misionariedad. Si no ocurre esta renovación, dichas estructuras y modos parroquiales seguirán manifestando más bien el desánimo, el cansancio, la dificultad, la burocratización $\mathrm{y}$ el funcionalismo.

Las categorías pastorales de encuentro, de diálogo y de envío son el mejor modo que tiene la parroquia para vivir eclesialmente el discipulado misionero. Debe predominar en la nueva organización parroquial una lógica predominantemente integradora y no agregativa, que dé origen a unidades pastorales coordinadas que ayuden a superar la incapacidad de muchas parroquias de realizar por sí solas su propuesta pastoral. Hoy, más que antes, es imprescindible que cada una de ellas entre en la

comunión en la palabra de Dios y los Sacramentos. Consultar, igualmente, G. F. Mariconti, "Il parroco...", 252. También en Congregación para el Clero, Instrucción El Presbitero, nn. 223-24. 
dinámica de esa comunión misionera con la Iglesia particular, se articule en vicarías o zonas pastorales, sea un centro de coordinación y de animación de comunidades, de grupos, movimientos y nuevas realidades eclesiales y pequeñas comunidades, y sea creativa al momento de proponer nuevas formas de organización y gobierno. Es necesario contar hoy con parroquias en red, es decir, relacionadas. La parroquia -lo queremos reafirmar- no es principalmente una estructura, un edificio o un territorio, sino que es presencia misionera de la Iglesia en la sociedad y en el mundo; una realidad teológica, no administrativa, en la que el fiel entra en contacto con la Palabra de Dios y desde la cual sale a anunciarla.

La Nueva Evangelización, en el contexto del Año de la Fe, hunde sus raíces en lo más esencial de la Iglesia. Esta es nueva, justamente porque consiste en el esfuerzo programático y paradigmático, de adecuación de sus personas e instituciones y de cada una de sus comunidades y fieles en particular al desafío misionero que significa ser bautizado. La Nueva Evangelización, como hemos establecido en estas páginas, no es solo una experiencia de oración, sino, en primer término, una experiencia de comunión, un programa misionero y una nueva forma de respuesta apostólica. No organizacional, sino apostólica. En este mismo contexto evangelizador, de discípulos y misioneros, he podido establecer que la parroquia es un lugar privilegiado en el cual los fieles tienen la posibilidad de tomar conciencia no solo de su pertenencia eclesial, sino, sobre todo, de su propia y particular responsabilidad pastoral y misionera. En este camino de colaboración y corresponsabilidad, la comunión entre sacerdotes, diáconos, religiosos y laicos, y su disponibilidad a trabajar juntos, constituyen la premisa necesaria de un modo nuevo de hacer pastoral.

En el fondo, nuestro planteamiento propone, gracias al impulso misionero del Año de la $\mathrm{Fe}$, la creación de un proyecto común de pastoral parroquial que facilite la existencia de uno orgánico y sistemático al servicio de la trasnmisión de la fe. La Nueva Evangelización señala en la parroquia la necesidad de una pastoral integral que conduzca a una transmisión de la fe en la que intervengan todos los bautizados según sus distintos carismas. La misionareidad de la parroquia está ligada a la capacidad que esta tenga de proceder, no por sí sola, sino articulando en su programación pastoral el camino indicado por las orientaciones pastorales de la diócesis y por las diferentes intervenciones del magisterio del obispo. En este desafío, el párroco no tiene solo una tarea de coordinación e integración, 
sino de verdadera guía de la pastoral de conjunto, llamando a todos a vivir la comunión diocesana y pidiendo a cada uno que reconozca la parroquia propia como presencia concreta y visible de la Iglesia particular en aquel lugar. No deben faltar, además, iniciativas orgánicas de propuesta del mensaje cristiano, de sus contenidos, de su validez y de su credibilidad. A la hora de elaborar este itinerario es imprescindible que el párroco no solo se preocupe de que los fieles sean adoctrinados en las verdades de la fe y formados en la catequesis, sino, principalmente, de fomentar el ardor misionero en cada uno de ellos, animar las iniciativas con las que se promueva el compromiso evangelizador de cada uno. El desafío suyo será conocer y coordinar las distintas confluencias y peculiaridades que constituyen la fisonomía de esa determinada parroquia, para que se manifieste en ella lo que la Iglesia es: misterio de comunión en tensión misionera. En la realización de este proyecto de pastoral evangelizadora, orgánica y sistemática, cada parroquia puede adaptar a su situación religiosa, social y cultural la concreción del mismo. De este modo la parroquia, que es una determinada comunidad de fieles, crea comunidad, sirve a la comunidad de personas que profesan la fe, alimenta y sustenta el testimonio de fe de los fieles que la habitan y la constituyen en una comunidad misionera. El párroco, especialmente, deberá crear modos, actitudes, espacios y tiempos para el encuentro personal y celebración comunitaria de la fe entre sus miembros.

Comprendida y estructurada desde este principio hermenéutico, como comunidad de fe misionera, la parroquia está llamada a convertirse en la Iglesia, y, para el mundo, en signo de comunión, no solo ad intra-lo que supone la integración de carismas, ministerios, funciones y oficios-, sino también ad extra, lo que implica un salir a la búsqueda de aquellos que se han alejado de la comunidad y de aquellos que nunca han pertenecido a ella. Para poder lograr lo anterior, creemos que no es suficiente una burocracia central, sino que es preciso hacer crecer en la parroquia la colegialidad, la corresponsabilidad y la solidaridad, lo cual constituiría una verdadera riqueza para todos. El párroco y los demás presbíteros, cada uno de los fieles y cada pequeña comunidad no pueden vivir encerrados sobre sí mismos, sino abiertos a toda la parroquia, la zona pastoral, la diócesis a la cual pertenece y la sociedad en la cual se encuentra.

Cada parroquia deberá voluntariamente valerse de los instrumentos pastorales ofrecidos por la Iglesia diocesana, en particular por las ofici- 
nas y servicios de la curia. Se hará necesario entretejer colaboraciones entre personas, instituciones e institutos de vida consagrada que en la predicación evangélica tienen un específico carisma, como también con asociaciones laicales y movimientos eclesiales. Solo de este modo será capaz de acompañar, de ir más allá del mero escuchar, anunciando el Evangelio desde la conversión de objetivos, métodos, organizaciones y tejiendo, a través del anuncio, relaciones directas con todos sus habitantes -cristianos y no cristianos-, partícipes de la vida de la comunidad o en sus márgenes.

La parroquia de rostro misionero no es solo aquella que está guiada por un párroco renovado, sino sobre todo, la que mantiene sus puertas abiertas, facilita la escucha y el encuentro con la palabra de Dios, promueve el diálogo interreligioso y ecuménico, escucha y comprende a la sociedad en donde se encuentra, se hace accesible y acogedora, valida y valora el otro y el mundo. Se ha acabado el tiempo del párroco que vive su ministerio de modo aislado y solo mandando; se ha superado la parroquia que se limita al cuidado pastoral de los creyentes y no escucha a los no creyentes. Hoy en día el camino misionero de la parroquia, camino dialogal y de colaboración, se confía, con la Nueva Evangelización, a la responsabilidad de toda la comunidad parroquial. La parroquia de rostro nuevo, la parroquia misionera, es la parroquia de todos, no solo la del párroco y de los demás presbíteros que colaboran con él. Esto nos recuerda que todos son y se deben experimentar como servidores de la misión en una comunidad responsable, sobre todo en los consejos pastorales parroquiales, en unión con los diocesanos, en los movimientos apostólicos, en los religiosos que están presentes en la parroquia. Formas específicas de corresponsabilidad en la parroquia son las que se configuran en los organismos de participación, especialmente los consejos pastorales parroquiales, lo que exige valorar dentro de ella los espacios del diálogo cultural, como las salas de la comunidad, los centros culturales, el asociacionismo de ambiente, los medios de comunicación sociales. Su identidad de espacio elegido para el discernimiento comunitario manifiesta la naturaleza de la Iglesia como comunión. Estos pueden convertirse progresivamente en el espacio en donde hacer madurar la capacidad de proyección y de verificación pastoral. Prescindir de alguno de los distintos agentes misioneros significará no construir la comunidad misionera. 
La renovación de la parroquia en perspectiva misionera no disminuye para nada el papel de presidencia del presbítero, sino que exige que este lo ejerza con el sentido evangélico del servicio a todos, en el reconocimiento y la valoración de todos los dones que el Señor ha difundido en la comunidad, haciendo crecer la corresponsabilidad. Al párroco, si busca realizar una buena cura pastoral, le corresponde presidir, animar y moderar la participación de todos los demás fieles que constituyen esa determinada comunidad de fieles. Tendrá que verse cada vez más dentro de un presbiterio y dentro de una multiplicidad de ministerios e iniciativas: en la parroquia, en la diócesis y en sus articulaciones. El párroco será menos el hombre del hacer y de la intervención directa y más el hombre de la comunión; y por ello tendrá que ocuparse de promover vocaciones, ministerios y carismas. La misionareidad de la parroquia exige que los espacios de la pastoral también se abran a nuevas figuras ministeriales, reconociendo tareas de responsabilidad a todas las formas de vida cristiana y a todos los carismas que el Espíritu suscita. Figuras nuevas al servicio de la parroquia misionera. En esta línea, solo considerando, integrando y animando la diversidad, el párroco será aquello que debe ser: vínculo visible de comunión, servidor de la misión, colaborador y dinamizador de la comunión misionera.

La palabra de Dios nos señala la Nueva Evangelización en el Año de la $\mathrm{Fe}$, no solo se escucha y medita, sino que impele a la parroquia a una nueva manera de comprenderse y organizarse. Esto plantea que, al momento de comprender, renovar, establecer y utilizar las estructuras de gobierno parroquial, la naturaleza misionera de la Iglesia tiene prioridad. Las iniciativas fructíferas de evangelización y catequesis requieren organismos parroquiales de gobierno y apostólicos, que superen cualquier clase de división y burocracia eclesiástica. Me refiero a superar la noción de control y de autoritarismo que pueden hacerse presente en la estructura organizativa de la parroquia, caracterizada por meros procedimientos explícitos y regularizados, división de responsabilidades y especialización del trabajo y jerarquía de mando, que acalla el anuncio y paraliza la misión. La palabra de Dios es el criterio para el redescubrimiento y la profundización de la imagen original y originante de lo que ella es: una determinada comunidad misionera de fieles, que si bien forma parte de la estructura terrena de la Iglesia, nace de la Palabra que escucha; una estructura eclesial que está entre la gente y que va a las periferias de la cultura y de la sociedad como portadora del Evangelio 
y no de estructuras, procedimientos, cursos y requisitos. La parroquia, especialmente asumirá la responsabilidad que le corresponde, de ser motor de la evangelización, cuando proponga a sí mismo y a sus fieles una pastoral de conjunto, fruto de la sinodalidad y del diálogo, del testimonio y anuncio del Evangelio. La novedad que la Nueva Evangelización le comunica a la parroquia "prestadora de servicios sacramentales", es que ella es una comunidad de discípulos y misioneros de Jesucristo, y que, por lo mismo, no puede ser sino instrumento de una experiencia eclesial vida de fe y no de una experiencia privada, individualista o subjetiva.

La parroquia, como hemos establecido en estas páginas, no es el único espacio por donde el ser humando entra a formar parte de la Iglesia; como tampoco el único medio a través del cual cada uno de los fieles entra y realiza su relación con la Iglesia, se alimenta de las Escrituras, se nutre por los sacramentos, y, como consecuencia de lo anterior, aprende a convertirse en discípulo de Cristo, en evangelizador y responsable de la misión de la Iglesia. Creemos que ella es un espacio eclesial que sigue siendo en la actualidad válido al momento de señalar que la Iglesia es una comunidad de discípulos y misioneros; sigue siendo el entorno habitual de la vida espiritual de los fieles, cuya finalidad está en encarnar el Evangelio en la vida de todos sus miembros. Sin tregua debería animar a sus miembros a convertirse en agentes de la Nueva Evangelización, dando testimonio con sus palabras y sus vidas de una pastoral creíble. Enraizada en este tiempo de misión, tendrá que cuidar y vivir su condición de unidad básica de misión y comunión eclesiales, actualizando la imagen conciliar de la IglesiaComunión. Lo anteriormente afirmado exige, no solo en el párroco sino también en todos los que participan de esa determinada comunidad de fieles, una conversión pastoral tal que promueva una conversión personal, una reforma de las estructuras del gobierno pastoral que estén al servicio de una red evangelizadora de personas y movimientos, de comunidades eclesiales de base y de pequeñas comunidades y grupos, capaces de suscitar la fe y formar discípulos misioneros que la anuncien. La comunidad parroquial entera, especialmente los líderes de la parroquia, deberían fomentar tal evangelización en un espíritu de hospitalidad y acogida a través de ministerios de incidencia y justicia social, y no solo con una eficiente administración de sacramentos.

La dinámica de la Nueva Evangelización y la naturaleza comunitaria de la parroquia desaconsejan y excluyen que el párroco concentre en sí 
todas las funciones evangelizadoras; lo anterior no solo por la imposibilidad práctica de realizarlas de modo adecuado, sino, sobre todo, porque ese injustificado protagonismo y exclusivismo pastoral disminuiría gravemente la riqueza de la particularidad y la competencia de los otros carismas y vocaciones presentes en ella. Todos los miembros de esta determinada comunidad de fieles han de orientar su pertenencia a la parroquia a partir del anuncio de la Fe que nace desde la óptica de la Nueva Evangelización, suscitando la participación y la corresponsabilidad de tantos otros. La promoción y búsqueda de una comunión apostólica será propuesta por el párroco como estímulo del apostolado comunitario en el que los fieles -cada uno de ellos y todos juntos- se comprometan con la acción evangelizadora y misionera de toda la Iglesia. La acción evangelizadora debería, entonces, permanecer enraizada en la parroquia no solo como estructura de gobierno y organización pastoral, sino como modo de ejercicio de las potestades de gobierno del párroco. La parroquia debería configurar sus estructuras de gobierno actuales y nuevas, recordando que ella es instrumento insustituible de la animación de todo el apostolado individual, lugar de encuentro y unidad de los grupos de fieles, asociaciones, movimientos y comunidades de base, en donde sus miembros, en la vida diaria y personal, conjuguen la participación, libre y creativa, con la comunión eclesial vivida desde la fe, conditio sine qua non de la Nueva Evangelización. Consciente de estas responsabilidades, es deber personal del párroco, junto a sus colaboradores y cooperadores, promover y programar la predicación, organizar la catequesis y preparar los programas de evangelización, de modo tal que haga experimentar a cada uno de los miembros de esa determinada comunidad de fieles encomendada a su cuidado pastoral, el significado de la vocación bautismal; es decir, la convicción de estar llamados por Dios para seguir a Cristo y para colaborar personalmente en la misión de la Iglesia.

En este volver a proponer el Evangelio a los adolescentes, adultos jóvenes, solteros, matrimonios, separados, fieles en situación irregular, padres, familias, enfermos, inmigrantes y discapacitados, o a cualquier persona que ya no esté cercana a la experiencia creyente de la fe, la parroquia debe proporcionar a la Iglesia una comunidad de fieles formados en el Evangelio que puedan acompañar a los que están regresando a la Iglesia y guiarlos a lo largo de su camino de fe. En la realización de esta propuesta eclesial, el Evangelio invita al párroco, a toda esa determinada 
comunidad de fieles, a los organismos de participación y gobierno, a constituirse en instrumentos preciosos de una Pastoral Misionera.

Creemos que la llamada a la Nueva Evangelización exige a la parroquia el inevitable replanteamiento de su estructura organizativa, evitando la burocratización de su estructura misionera: debe dejar de ser una organización y coordinación, administradora de sacramentos y de cursos, para transformarse en verdaderos centros de espiritualidad y de apostolado, en una casa y escuela de comunión; lugar eclesial de espiritualidad y apostolado en el que se aprende la comunión y la corresponsabilidad en la misión de la Iglesia. La Nueva Evangelización pasa por contar con una parroquia evangelizada y evangelizadora, instrumento privilegiado en la construcción de una Iglesia particular más comunitaria y, por lo mismo, más evangelizadora. La Nueva Evangelización es una nueva oportunidad para que las parroquias se transformen, con fidelidad creativa, en una comunidad de discípulos misioneros. La propuesta de una Nueva Evangelización se debe traducir, entonces, en la capacidad de parte de la parroquia de vivir en modo renovado la propia experiencia comunitaria de la Fe y del anuncio del Evangelio dentro de las nuevas situaciones culturales que se han creado en estas últimas décadas.

La Nueva Evangelización nos recuerda que en la parroquia los fieles no son solo oyentes de la Palabra, sino, sobre todo, sujetos y protagonistas de la misión, para lo cual la parroquia tendrá necesidad de tender a la creación de centros formativos de distinto tipo, como escuelas de catequesis, escuelas elementales o de otro nivel, sedes para encuentros formativos de jóvenes, centros de asistencia caritativa y social y para el apostolado familiar, bibliotecas, etc. En resumen, una red organizada que pueda penetrar profundamente y de manera diversificada en los distintos ambientes y grupos de población.

El Año de la $\mathrm{Fe}$ es una invitación a una auténtica y renovada conversión, que interpela a la parroquia a transformase en una comunidad apostólica y misionera gracias al anuncio del Evangelio; a pasar desde una parroquia clerical hacia una comunidad de discípulos y misioneros. La Nueva Evangelización implica una parroquia de 'rostro nuevo'. La Nueva Evangelización es una gran oportunidad para la revitalización de la fe, es un tiempo-actividad de esperanza y renovación para la misión más honda de la Iglesia, un lugar teológico para ella misma, en cuanto es una determinada comunidad de fieles que promueve el encuentro per- 
sonal y comunitario con Cristo. La Nueva Evangelización, en este Año de la $\mathrm{Fe}$, hecho no solo disciplinar sino teológico y apostólico, es un llamado a la Iglesia y a cada bautizado a profundizar su propia fe, tener confianza en el Evangelio de Jesucristo y a poseer la voluntad de compartir ese Evangelio. La Nueva Evangelización es un tiempo de gracia que nos está ayudando a sentir la gran alegría de ser discípulos y misioneros.

Concluyo, con palabras del papa Francisco, quien, en su encíclica Lumen Fidei (39), nos recuerda que: "Es imposible creer cada uno por su cuenta. La fe no es únicamente una opción individual que se hace en la intimidad del creyente, no es una relación exclusiva entre el yo del fiel y el $T u ́$ divino, entre un sujeto autónomo y Dios. Por su misma naturaleza, se abre al nosotros, se da siempre dentro de la comunión de la Iglesia... Por eso, quien cree nunca está solo, porque la fe tiende a difundirse, a compartir su alegría con otros"73.

73 Papa Francisco, Encíclica Lumen Fidei 39. 
Resumen: La parroquia vive una crisis y, ante otras manifestaciones eclesiales, ha ido perdiendo importancia. Es necesario revitalizarla en clave misionera. Este trabajo es una reflexión teológico-pastoral, donde nos preguntamos por la identidad teológica, jurídica y pastoral de la parroquia, en el contexto es la Nueva Evangelización. Una renovación exige repensar la estructura parroquial: desde una coordinación de la administración de sacramentos y cursos a un centro de espiritualidad, de apostolado, de envío y de misión. Esto implica también nuevos ministerios, reconociendo tareas y responsabilidades a otras las formas de vida cristiana y a carismas que el Espíritu suscita.

Palabras clave: Parroquia, encuentro, comunión, misión, nueva evangelización, corresponsabilidad, colaboración.

Abstract : Parishes are becoming less significant in front of other, more recent, pastoral institutions. It seems necessary to stress its missionary dimension. The present paper offers a theological, canonical and pastoral view of the parish intended for the New Evangelization. This means a renewal of the structure of the parish, so as to be less a coordination centre of liturgical and catechetical services and more a support of spirituality and apostolate. This also means an openness to new ministries and charisms.

Keywords: Parish, encounter, communion, mission, new evangelization, shared responsibility, collaboration. 
